\title{
First detection of Eimeria species in Myanmar domestic goats with both microscopic and molecular methods
}

\author{
Saw Bawm ${ }^{1,2, *}$, Tay Zar Bhone Win ${ }^{1}$, Shwe Yee Win ${ }^{1}$, Lat Lat Htun ${ }^{1}$, Ryo Nakao ${ }^{3}$, and Ken Katakura ${ }^{3}$ \\ ${ }^{1}$ Department of Pharmacology and Parasitology, University of Veterinary Science, Yezin, 15013 Nay Pyi Taw, Myanmar \\ 2 Department of International Relations and Information Technology, University of Veterinary Science, Yezin, 15013 Nay Pyi Taw, \\ Myanmar \\ ${ }^{3}$ Laboratory of Parasitology, Faculty of Veterinary Medicine, Hokkaido University, 060-0818 Sapporo, Japan
}

Received 11 November 2019, Accepted 8 May 2020, Published online 19 May 2020

\begin{abstract}
Coccidiosis is of great economic importance in many farm animals. This study involved analysis of 280 faecal samples collected from 12 traditional goat farms from Nay Pyi Taw area, Myanmar. Faecal samples were examined by the flotation method and concentrated oocysts were identified on the basis of morphological characters. Of 280 faecal samples examined, $168(60.0 \%)$ were positive for Eimeria oocysts. Three different Eimeria species were identified and their positive detection rates in the herd were: E. arloingi (25.4\%), followed by E. hirci $(20.7 \%)$ and E. christenseni (13.9\%). Identifications were confirmed by $18 \mathrm{~S}$ rDNA and COI sequences. 18S rDNA sequences showed $100 \%$ homology with, respectively, E. christenseni reported from Australia, E. arloingi reported from Australia and Iran, and E. hirci from Australia. COI sequences of E. christenseni, E. hirci, and E. arloingi, respectively, exhibited 98.9\%, 98.4\%, and 98.5\% similarities with those reported from Australia. This is the first report of Eimeria infection in Myanmar goats.
\end{abstract}

Key words: Eimeria arloingi, Eimeria hirci, Eimeria christenseni, Domesticated goats, Myanmar.

\begin{abstract}
Résumé - Première détection d'espèces d'Eimeria chez les chèvres domestiques du Myanmar à l'aide de méthodes microscopiques et moléculaires. La coccidiose est d'une grande importance économique pour de nombreux animaux d'élevage. L'étude a impliqué l'analyse de 280 échantillons de matières fécales prélevés dans 12 fermes caprines traditionnelles de la région de Nay Pyi Taw, Myanmar. Les échantillons fécaux ont été examinés par la méthode de flottation et des oocystes concentrés ont été identifiés sur la base de caractères morphologiques. Sur 280 échantillons fécaux examinés, 168 (60,0\%) étaient positifs pour les oocystes d'Eimeria. Trois espèces différentes d'Eimeria ont été identifiées et leurs taux de détection positifs dans le troupeau étaient: E. arloingi $(25,4 \%)$, suivi par E. hirci $(20,7 \%)$ et E. christenseni $(13,9 \%)$. Les identifications ont été confirmées par les séquences d'ADNr $18 \mathrm{~S}$ et de COI. Les séquences d'ADNr 18S ont montré une homologie de $100 \%$ avec, respectivement, E. christenseni d'Australie, E. arloingi d'Australie et d'Iran et E. hirci d'Australie. Les séquences de COI d'E. christenseni, E. hirci et E. arloingi présentaient des similitudes de 98,9\%, 98,4\% et 98,5\%, respectivement, avec celles rapportées d'Australie. Il s'agit du premier signalement d'infection à Eimeria chez des chèvres du Myanmar.
\end{abstract}

\section{Introduction}

Coccidiosis of farm animals is caused by coccidial parasites of the genus Eimeria which develop in the small and the large intestines. Coccidiosis is of great economic importance in many farm animals, especially young animals, because of losses due to clinical disease (diarrhoea) and subclinical infections (poor weight gain in particular) and the required treatment costs. Many Eimeria infections in goats are asymptomatic; however, some species have been associated with diarrhoea and stunted growth $[6,33]$. Of the 16 Eimeria species identified in goats worldwide, E. arloingi, E. ninakohlyakimovae, E. christenseni, and $E$. caprina were considered to be the most pathogenic species [14, 18, 29, 35]. According to reports from Sri Lanka, Malaysia, China, and India, the most frequent species of Eimeria in goats in Asian countries are E. ninakohlyakimovae, E. christenseni, E. arloingi, E. parva, E. caprina, and E. alijevi [11, 14, 36, 42].

Different diagnostic methods are available for specific identification of Eimeria. Traditional methods are based mainly on oocysts morphological characteristics under microscopic examination, parasite biology, clinical signs in the affected animals,

\footnotetext{
*Corresponding author: bestshadow@gmail.com; sawvet@uvsyezin.edu.mm
} 
and typical macroscopic lesions assessed by lesion scores [22]. However, due to the presence of intraspecies variation, the morphological method is not fully reliable since natural infections by Eimeria are generally mixed with more than one species and several species have confusing features [22, 30, 43]. Furthermore, morphological observations combined with faecal examination are very labor-intensive and require a skillful classification technique. Molecular techniques have been reported as useful for species identification or classification of this genus to overcome the limitations of traditional methods [5, 16, 45], and have further demonstrated the phylogenetic position of each Eimeria species and phylogenetic clades [46, 21, 24]. Molecular characterization of Eimeria species from goats has been reported from Australia [1], India [41], and Iran [17].

Livestock production, especially goat farming, is important for the livelihood of millions of rural people in Myanmar because it contributes to food security and the creation of assets. However, information on Eimeria, the causal agent of coccidiosis, one of the most economically important diseases in goats, has never been reported from Myanmar. The aim of this study was to demonstrate the presence of Eimeria in native goats from Myanmar for the first time and to describe the species of parasites using molecular and morphological tools.

\section{Materials and methods \\ Study sites}

The study design was cross-sectional and the study was conducted on traditional goat farms at three different villages within the Nay Pyi Taw area. Nay Pyi Taw is located between latitude $19^{\circ} 45^{\prime} \mathrm{N}$ and longitude $96^{\circ} 60^{\prime} \mathrm{E}$ with the following climate characteristics: altitude $115 \mathrm{~m}$ above sea level; annual rainfall $1167 \mathrm{~mm}$; and annual temperature range 21.2-32.5 ${ }^{\circ} \mathrm{C}$. Sampling period was between March and May, 2017. Measurement of oocyst sizes and molecular examinations were performed at the Laboratory of Parasitology, Faculty of Veterinary Medicine, Hokkaido University, Japan.

\section{Sample collection and processing}

The study included 280 faecal samples (110 from males and 170 from females) collected from 12 traditional goat farms of indigenous breeds, Jade Ni and Htain San. Among the studied samples, 77 from kids under 4 months old, 110 from kids 4-12 months old, and 93 from animals older than 12 months, were examined for oocysts of Eimeria. The number of animals on each farm ranged between 10 and 80 . Animals were kept in a semi-intensive management system: they were kept in wooden sheds with raised slatted floors at night and in the morning, and allowed to graze in the afternoon for $3-5 \mathrm{~h}$ on common pasture, on road sides or on uncultivated land. No feed supplementation was provided on any farm and there was no history of anticoccidial treatment against coccidiosis.

Faecal samples were collected directly from the rectum and stored on ice or in a refrigerator $\left(4.0^{\circ} \mathrm{C}\right)$ until microscopic examination. The presence of oocysts in the faecal samples was examined by the flotation method using Sheather's sugar solution ( $\mathrm{SG}=1.26)$ as described by Salant et al. [34]. The washed faecal samples were then mixed with sugar solution and centrifuged at $2500 \mathrm{rpm}$ for $10 \mathrm{~min}$. The oocysts were then collected from the tops of the centrifuge tubes. Concentrated oocysts were identified on the basis of morphological characters. The Eimeria species were determined based on morphology of oocysts and sporocysts (shape, colour, form index, micropyle and polar cap, and presence or absence of residual body) [10]. A total of 10 morphologically characterized oocysts of each species was examined and photographed using microscopy. Then the length and width of 50 randomly selected sporulated oocysts of each sample were measured at $400 \times$ magnification using cellSens Imaging software (Olympus, Japan). Among the positive samples, 20 were randomly selected and oocysts per gram (OPG) were determined quantitatively by the modified McMaster method [23].

\section{DNA extraction}

Oocyst samples were purified in several steps before DNA preparation. For each DNA preparation, approximately 500 morphologically similar oocysts were collected by using PicoPipet (Nepa Gene, Japan). Then the oocysts were washed three times with distilled water and finally concentrated to a volume of $50 \mu \mathrm{L}$. Before DNA extraction, the oocyst samples were transferred to a $1.5 \mathrm{~mL}$ centrifugal tube and five cycles of freezing/thawing were performed; quick freezing was performed in a $-80{ }^{\circ} \mathrm{C}$ freezer for $5 \mathrm{~min}$, while quick thawing was conducted in a $37{ }^{\circ} \mathrm{C}$ water bath for $5 \mathrm{~min}$. Oocysts were crushed using $0.2 \mathrm{~mm}$ glass beads (Biomedical Science, Tokyo, Japan) followed by vortexing for $5 \mathrm{~min}$ at $2000 \mathrm{rpm}$ [13]. Thereafter, DNA was extracted from the lysate using a PowerFecal ${ }^{\circledR}$ DNA isolation kit (MO BIO Laboratories, USA), according to the manufacturer's instructions. The DNA was quantified spectrophotometrically and stored at $-20{ }^{\circ} \mathrm{C}$ for subsequent analysis.

\section{Identification of Eimeria species by PCR}

The specific primers for both the cytochrome oxidase I (COI) and 18S rRNA genes were used based on the corresponding published sequences of related species. A partial mitochondrial COI gene sequence (723 bp) was amplified using a nested PCR, as described by Al-Habsi et al. [1]. A region of the 18S rRNA gene (630 bp) was amplified with the forward primer mCYC1FE $5^{\prime}$ - TACCCAATGAAAACAGTTT - $3^{\prime}$ and the reverse primer mCYC2RB $5^{\prime}$ - CAGGAGAAGCCAAGGTAGG - 3' [15]. PCR was performed in a $25 \mu \mathrm{L}$ volume containing $1 \mu \mathrm{L}$ of DNA template, $0.5 \mu \mathrm{L}$ of Tks Gflex DNA polymerase $(1.25 \mathrm{U} / \mu \mathrm{L})$ (TaKaRa Bio Inc., Shiga, Japan), $12.5 \mu \mathrm{L}$ of $2 \times$ Gflex PCR Buffer $\left(\mathrm{Mg}^{2+}\right.$, dNTP plus, TaKaRa Bio Inc.), and $10 \mu \mathrm{L}$ of nuclease-free water (Promega, Madison, WI, USA). Thermocycling for both target genes was done with an initial denaturation step for $5 \mathrm{~min}$ at $94{ }^{\circ} \mathrm{C}$, 45 cycles of denaturation for $30 \mathrm{~s}$ at $98{ }^{\circ} \mathrm{C}$, annealing for $30 \mathrm{~s}$ at $55^{\circ} \mathrm{C}$, and extension for $2 \mathrm{~min}$ at $68{ }^{\circ} \mathrm{C}$, and a final extension for $7 \mathrm{~min}$ at $68^{\circ} \mathrm{C}$. The second PCR was conducted with $1 \mu \mathrm{L}$ of the first PCR amplification mixture as the template 
Table 1. Oocyst morphological features for Eimeria spp. from Myanmar goats (characterisation according to Eckert et al. [10]).

\begin{tabular}{lcc}
\hline Eimeria spp. & Oocyst size mean (range) $1 \mathrm{~m}$ & Characteristics \\
\hline E. christenseni & Height $=33.3(30.5-35.6)$ & Ellipsoid-ovoid, bi-layered \& thick wall, with micropolar cap, \\
& Width $=21.3(18.1-25.9)$ & broadly elongated, ovoid sporocyst \\
E. arloingi & Height $=22.9(21.2-23.0)$ & Ellipsoid-ovoid, bi-layered \& thick wall, with micropolar cap, \\
& Width $=18.5(17.2-20.1)$ & elongated ovoid sporocyst \\
E. hirci & Height $=20.03(18.3-22.1)$ & Roundish oval, bi-layered wall, with micropolar cap, \\
& Width $=18.6(16.1-21.3)$ & slightly ovoid-round sporocyst \\
\hline
\end{tabular}

after 10-fold dilution in nuclease-free water. The PCR products were examined by $1 \%$ (for COI gene) and $2 \%$ (for $18 \mathrm{~S}$ rRNA gene) Tris-acetate-EDTA (TAE) agarose gel electrophoresis, and stained with Red Safe Nucleic Acid Staining Solution (iNtRON Biotechnology Inc., Sungnum, Korea).

DNA fragments obtained from the PCR were excised from the gel and purified with a NucleoSpin ${ }^{\circledR}$ Gel and PCR Clean-up Kit (MACHEREY-NAGEL, Düren, Germany), according to the manufacturer's instructions, and submitted for direct sequencing using an Applied Biosystems 3130 Genetic Analyzer with a BigDye v3.1 Terminator cycle sequencing kit (Applied Biosystems, Inc., Carlsbad, CA, USA).

\section{Phylogenetic analysis}

Multiple sequence alignment was performed using the sequence analysis software package ATGC version 7 (GENETYX Corporation, Tokyo, Japan). Further manual alignment and determinations of pairwise percentage of sequence identity were done by ClustalW. Phylogenetic relationships between sequences were assessed by using the maximum likelihood method in MEGA, version 6.06 [38]. A phylogenetic tree was constructed for Eimeria at the 18S locus with additional isolates from GenBank. Bootstrap analysis was done using 1000 replicates/tree. The obtained sequences were compared to those from the NCBI nucleotide database (http://www.ncbi. nlm.nih.gov/nuccore/). The nucleotide sequences for the analyzed COI and 18S rRNA genes of Eimeria were deposited in GenBank with accession numbers LC507792-LC507798 and LC508121-LC508123, respectively.

\section{Statistical analysis}

Statistical analysis was performed using Epi Info ${ }^{\mathrm{TM}}$ software version 7.2 (https://www.cdc.gov/epiinfo/pc.html). Differences in coccidial occurrence among different age groups were analysed using Chi-square test and $p<0.05$ was considered significant.

\section{Results}

\section{Microscopic examination}

Of 280 faecal samples examined, 168 (60.0\%) were positive for Eimeria oocysts: 55 were from kids $(71.4 \%$ of 77 kid samples), 61 from weaners (55.4\% of 110 weaner samples) and 52 from adult goats (55.9\% of 93 adult samples). The morphological features (shape and size) of the oocysts and
Table 2. Percentage of infections in faecal samples for each Eimeria species in goats.

\begin{tabular}{lcccc}
\hline Species & \multicolumn{3}{c}{ No. of infected animals } & $\begin{array}{c}\text { Total no. } \\
\text { infected (\%) }\end{array}$ \\
\cline { 2 - 4 } & $\begin{array}{c}\text { Kid } \\
(<4 \mathrm{mo})\end{array}$ & $\begin{array}{c}\text { Weaner } \\
(4-12 \mathrm{mo})\end{array}$ & $\begin{array}{c}\text { Adult } \\
(>12 \mathrm{mo})\end{array}$ & \\
\hline E. christenseni & 10 & 10 & 15 & $39(13.9)$ \\
E. arloingi & 25 & 27 & 22 & $71(25.4)$ \\
E. hirci & 20 & 24 & 15 & $58(20.7)$ \\
\hline
\end{tabular}

Table 3. The number of Eimeria species present in individual positive faecal samples.

\begin{tabular}{lccccc}
\hline Age class & No. & Positive (\%) & \multicolumn{3}{c}{$\begin{array}{c}\text { No. of species in } \\
\text { sample (\%) }\end{array}$} \\
\cline { 3 - 6 } & & & 1 & 2 & 3 \\
\hline Kid $<4$ mo & 77 & $55(71.4)^{*}$ & 46 & 9 & 0 \\
Weaner 4-12 mo & 110 & $61(55.4)$ & 45 & 13 & 3 \\
Adult $>12$ mo & 93 & $52(55.9)$ & 35 & 16 & 1 \\
\hline
\end{tabular}

${ }^{*} \chi^{2}=4.22955, p<0.05$.

sporocysts from the three identified Eimeria species were consistent with ranges previously reported for the respective species (Table 1). In 20 tested samples, OPG in two goats was $>10,000$, whereas OPG in 18 goats ranged from 100 to 6000. Three different Eimeria species were identified and their positive detection rates in the herd were: E. arloingi (25.4\%), followed by E. hirci (20.7\%), and E. christenseni (13.9\%). The species detected and their positive rates over the age classes are given in Table 2. Among positive goats, the double infection rate with two Eimeria species was $22.6 \%$ (38/168) and the triple infection rate with three Eimeria species was only $2.4 \%$ (4/168). The frequency of multiple infections was higher in kids compared with other age classes (Table 3). Moreover, kids showed a higher risk for infection than other age groups $\left(\chi^{2}=4.22955, p<0.05\right)$. There was no significant association between sex and Eimeria infection $\left(\chi^{2}=0.994652, p=0.3186\right)$.

\section{Phylogenetic analysis of the three Eimeria species based on the 18S rRNA and COI genes}

Three 18S sequences obtained from this study showed $100 \%$ homology with E. christenseni (KX845684) reported from Australia and grouped in the same clade. Two sequences grouped in a clade with E. arloingi (KX845686 and KC507792) reported from Australia and Iran with 100\% homology. Two sequences were $100 \%$ identical to $E$. hirci (KX845685) from Australia (Fig. 1). 


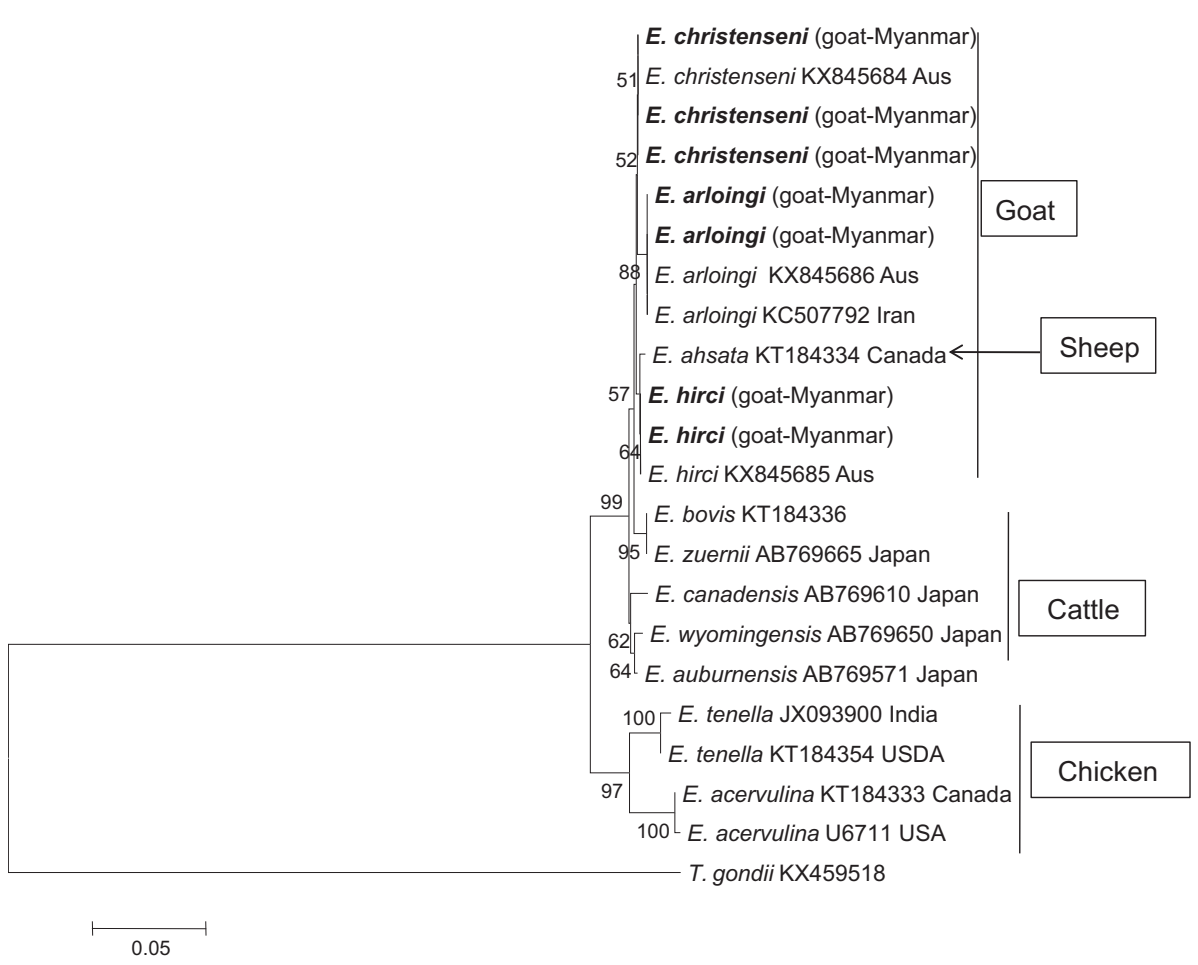

Figure 1. Phylogenetic tree of Eimeria species based on the 18S rRNA gene. The tree was built with the maximum likelihood method. Numbers indicate bootstrap percentages (1000 replicates). The scale indicates the divergence time.

COI sequences of E. christenseni, E. hirci, and E. arloingi, respectively, exhibited $98.9 \%, 98.4 \%$, and $98.5 \%$ similarities with those reported from rangeland goats in Australia (KX857468, KX857469, and KX857470) (Fig. S1).

\section{Discussion}

There are about 8.13 million goats in Myanmar [12], mostly reared for meat, although milk is also used by households in some areas [27]. More than half of the national goat population is found in the central region, the area studied. Economic losses due to coccidiosis have been reported by many researchers elsewhere [20]. The factors causing economic losses by coccidiosis in domestic animals include high mortality rates and lowered productivity due to poor growth, together with costs of anticoccidials, drug administration and disinfection [9]. In addition, in the case of moderate infection without clinical signs, these losses can be linked to reduced production (due to poor weight gain in particular) and infected animals appear more susceptible to other infections [6]. In two studies carried out in East Africa, coccidiosis appears to be a secondary cause of mortality amongst small ruminants in comparison with other parasitic or infectious diseases such as pneumonia or helminthiasis $[19,26]$.

In Myanmar, morphological and molecular data on Eimeria species in goats were not available. The present study has shown that a moderately high occurrence of Eimeria species (60.0\%), particularly E. arloingi (52.7\%), and E. hirci (43.0\%), exists in Myanmar goats. Based on microscopic examination, studies on goats in dry tropical areas of Africa, such as in Senegal [40], Nigeria [44], and Zimbabwe [7], have shown high prevalence of Eimeria species infection, the common species being E. arloingi (64-80\%) and E. christenseni (60\%). Comparable studies from Asian countries such as Sri Lanka, Malaysia, India, and China also showed low to high prevalence of E. arloingi (21-73\%) and E. christenseni (63-78\%) [11, 14, $36,42]$. In contrast with other studies [42, 44], the occurrence of single-species infection was higher than mixed-species infection in this study. The reason might be the rearing system in our study area. The goats were reared in a semi-intensive management system, with average herd size ranging between 10 and 80, which is a smaller herd size than other reports [32]. According to a report by Tomczuk et al. [39], the dissemination of coccidia species is facilitated by rearing with high population density. As a result, the farming system in our study area might not favour the abundance and dissemination of Eimeria spp. In this study, we focused on the Nay Pyi Taw area only, and thus different species of Eimeria might be observed from goats in other parts of the country.

The current findings revealed that among the examined samples, $71.4 \%$ of 77 kids were found to be positive, which is a higher association with Eimeria infection $(p<0.05)$ than weaners and adults with positive rates of $55.4 \%$ and $55.9 \%$, respectively. Frequency of infection was lower in adults probably due to more developed immunity in adults compared to kids [4]. These results are in agreement with previous reports by Balicka-Ramisz [3], Wang et al. [42], and Silva et al. [37].

Notwithstanding that E. arloingi and E. christenseni have been reported as pathogenic species, no clinical signs of coccidiosis were seen in any of the examined goats. Most samples collected from goats consisted of well-formed faeces and only a few had soft-formed faeces but severe diarrhoea was not 
seen in any of the animals examined. Some reports have shown the existence of genetic resistance to gastrointestinal parasites and coccidiosis in indigenous goats in Asia and Africa [8, 25, $28,31]$. In our study areas, all goats were allowed to graze in the afternoon for 3-5 h on common pasture shared with other goats in the same village. Pasture in the study area was mostly grazed by goats and cattle. Since Eimeria species are hostspecific, infection cannot be transmitted from other animal species. The parasites seemed to be circulating among goats grazing this area and the goats might become chronic carriers. The infected goats without clinical symptoms in a herd retain their infections year-round, continually contaminating the environment with oocysts. Therefore, the infected goats serve as a source of re-infection and of new infections for young kids [2].

Diagnosis of Eimeria species in goats mainly relies on morphological examination. In this study, to support our microscopic identifications, findings were substantiated using molecular techniques based on PCR amplifying the parasite $18 \mathrm{~S}$ rRNA and COI genes. The 18S rRNA gene has been widely used for molecular detection of Eimeria species; however, since this gene is highly conserved, it is not appropriate to evaluate genetic diversity among Eimeria species. The phylogenetic tree generated in this study suggests a shared evolutionary history for Eimeria in cattle (E. bovis and E. zuernii), sheep (E. ahsata) and goats, and therefore they may have evolved from one common ancestor. In addition, high similarity of $18 \mathrm{~S}$ rDNA sequences between $E$. arloingi and E. ahsata has also been reported from Iran [17]. Though the COI gene has been suggested as a suitable target to differentiate closely related Eimeria species in small ruminants [1], the number of sequences available in GenBank is still limited. We can compare COI sequences reported from rangeland goats in Australia only. Thus, the sequence data obtained in the present study will make a contribution to understand the genetic diversity and geographic distribution of Eimeria species infecting small ruminants worldwide.

In terms of poverty alleviation in Myanmar, it is important to maintain and develop goat-related industries. Proper management should be practiced to prevent losses and reduced productivity from coccidiosis in young animals by: reducing the level of environmental contamination by infectious oocysts; minimizing stress; and avoiding crowding of kids [2, 6]. As in other regions, the significance of coccidiosis still seems to be underestimated by both veterinarians and farmers. It is necessary to be aware of the problem and practice control strategies such as maintaining hygienic conditions and using anticoccidial drugs.

In conclusion, this is the first report of Eimeria species from goats in Myanmar. A further innovation in Myanmar was that identification was undertaken by morphological determination and confirmed by molecular analysis. Further research is needed to elucidate the prevalence of Eimeria infection in goats and its relationship with the management system, and seasonal and geographical variations for the whole country. In addition, quantitative analysis for Eimeria infection should also be considered and its economic impact in future studies. This report provides occurrence and molecular information on the Eimeria species in Myanmar goats that could be used for future molecular investigations.

\section{Supplementary materials}

Supplementary material is available at https://www.parasitejournal.org/10.1051/parasite/2020037/olm

Figure S1. Alignment of the COI partial sequences isolated in this study with those of E. christenseni, E. arloingi, and E. hirci reported in GenBank. Dots indicate bases that are identical to the reported data.

Acknowledgements. We would like to thank officials from the Ministry of Agriculture, Livestock and Irrigation, and farmers for helping with sample collection. The authors gratefully acknowledge Dr. Andrew White (English Teacher, Australian Volunteer) for editing English grammar. We would also like to thank the Invitational Fellowship Program of the Japan Society for the Promotion of Science (JSPS).

\section{Conflict of interest}

The authors declare that they have no competing interests.

\section{References}

1. Al-Habsi K, Yang R, Ryan U, Miller DW, Jacobson C. 2017. Morphological and molecular characterization of three Eimeria species from captured rangeland goats in Western Australia. Veterinary Parasitology: Regional Studies and Reports, 9, 75-83.

2. Baker NF. 1975. Control of parasitic gastroenteritis in goats. Journal of the American Veterinary Medical Association, 167, 1069-1075.

3. Balicka-Ramisz A. 1999. Studies on coccidiosis in goats in Poland. Veterinary Parasitology, 81, 347-349.

4. Cavalcante ACR, Teixeira M, Monteiro JP, Lopes CWG. 2012. Eimeria species in dairy goats in Brazil. Veterinary Parasitology, 183, 356-358.

5. Ceré N, Licois D, Humbert JF. 1995. Study of the inter- and intraspecific variation of Eimeria spp. from the rabbit using random amplified polymorphic DNA. Parasitology Research, 81, 324-328.

6. Chartier C, Paraud C. 2012. Coccidiosis due to Eimeria in sheep and goats, a review. Small Ruminant Research, 103, 84-92.

7. Chhabra RC, Pandey VS. 1991. Coccidia of goats in Zimbabwe. Veterinary Parasitology, 39, 199-205.

8. Chiejina SN, Behnke JM. 2011. The unique resistance and resilience of the Nigerian West African Dwarf goat to gastrointestinal nematode infections. Parasites \& Vectors, 4, 12.

9. Cornelius CE. 1980. The economic impact of coccidiosis in domestic animals, in Advances in Veterinary Science and Comparative Medicine, Fitzgerald PR, Brandly CA, Editors. Academic Press: New York, NY, USA. p. 121-143.

10. Eckert J, Braun R, Shirley MW, Coudert P. 1995. Guidelines on techniques in coccidiosis research. Luxembourg, Western Europe: European Commission, DGXII. p. 103-117.

11. Faizal ACM, Rajapakse RPVJ. 2001. Prevalence of coccidia and gastrointestinal nematode infections in cross bred goats in the dry areas of Sri Lanka. Small Ruminant Research, 40, 233-238.

12. FAOSTAT. 2017. http://www.fao.org/faostat/en/\#data.

13. Haug A, Thebo P, Mattsson JG. 2007. A simplified protocol for molecular identification of Eimeria species in field samples. Veterinary Parasitology, 146, 35-45. 
14. Jalila A, Dorny P, Sani R, Salim NB, Vercruysse J. 1998. Coccidial infections of goats in Selangor, peninsular Malaysia. Veterinary Parasitology, 74, 165-172.

15. Jinneman KC, Wetherington JH, Hill WE, Omiescinski CJ, Adams AM, Johnson JM, Tenge BJ, Dang NL, Wekell MM. 1999. An oligonucleotide-ligation assay for the differentiation between Cyclospora and Eimeria spp. polymerase chain reaction amplification products. Journal of Food Protection, $62,682-685$.

16. Johnston DA, Fernando MA. 1995. Eimeria spp. of the domestic fowl: analysis of genetic variability between species and strains using DNA polymorphisms amplified by arbitrary primers and denaturing gradient-gel electrophoresis. Parasitology Research, 81, 91-97.

17. Khodakaram-Tafti A, Hashemnia M, Razavi SM, Sharifiyazdi H, Nazifi S. 2013. Genetic characterization and phylogenetic analysis of Eimeria arloingi in Iranian native kids. Parasitology Research, 112, 3187-3192.

18. Koudela B, Bokova A. 1998. Coccidiosis in goats in the Czech Republic. Veterinary Parasitology, 76, 261-267.

19. Kusiluka LJM, Kambarage DM, Harrison LJS, Daborn CJ, Matthew-man RW. 1998. Causes of morbidity and mortality in goats in Morogoro district, Tanzania: the influence of management. Small Ruminant Research, 29, 167-172.

20. Lassen B, Ostergaard S. 2012. Estimation of the economical effects of Eimeria infections in Estonian dairy herds using a stochastic model. Preventive Veterinary Medicine, 106, 258-265.

21. Lew AE, Anderson GR, Minchin CM, Jeston PJ, Jorgensen WK. 2003. Inter and intra-strain variation and PCR detection of the internal transcribed spacer 1 (ITS-1) sequences of Australian isolates of Eimeria species from chickens. Veterinary Parasitology, $112,33-50$

22. Long PL, Joyner LP. 1984. Problems in the identification of species of Eimeria. Journal of Protozoology, 31, 535-541.

23. MAFF. 1986. Manual of veterinary parasitological laboratory techniques. London, UK: Ministry of Agriculture, Fisheries and Food, HMSO. p. 78-90.

24. Morrison DA, Bornstein S, Thebo P, Wernery U, Kinne J, Mattsson JG. 2004. The current status of the small subunit rRNA phylogeny of the coccidian (Sporozoa). International Journal of Parasitology, 34, 501-514.

25. Onzima RB, Mukiibi R, Ampaire A, Benda KK, Kanis E. 2017. Between-breed variations in resistance/resilience to gastrointestinal nematodes among indigenous goat breeds in Uganda. Tropical Animal Health and Production, 49, 1763-1769.

26. Peeler EJ, Wanyangu SW. 1998. Infectious causes of small ruminant mortality in Kenya: a review. Small Ruminant Research, 29, 1-11.

27. Phyu PP, Pichler R, Soe O, Aung PP, Than M, Shamsuddin M, Diallo A, Periasamy K. 2017. Genetic diversity, population structure and phylogeography of Myanmar goats. Small Ruminant Research, 148, 33-42.

28. Pralomkarn W, Pandey VS, Ngampongsai W, Choldumrongkul S, Saithanoo S, Rattaanachon L, Verhulst A. 1997. Genetic resistance of three genotypes of goats to experimental infection with Haemonchus contortus. Veterinary Parasitology, 68, 79-90.

29. Razavi SM, Hassanvand A. 2007. A survey on prevalence of different Eimeria species in goats in Shiraz suburbs. Journal of Faculty of Veterinary Medicine, University of Tehran, 61, 373-376.

30. Reid WM. 1973. Coccidiosis immunity following early and late exposure to Marek's disease. Avian Diseases, 17, 66-71.
31. Rout PK, Bishop SC, Chauhan KK, Singh SK. 2015. Genetic resistance to natural coccidiosis infection in goats in a semi-arid region of India. Cogent Food \& Agriculture, 1, 1071928.

32. Ruiz A, González JF, Rodríguez E, Martín S, Hernández YI, Almeida R, Molina JM. 2006. Influence of climatic and management factors on Eimeria infections in goats from semiarid zones. Journal of Veterinary Medicine B, Infectious Diseases and Veterinary Public Health, 53, 399-402.

33. Ruiz A, Guedes AC, Munoz MC, Molina JM, Hermosilla C, Martín S. 2012. Control strategies using diclazuril against coccidiosis in goat kids. Parasitology Research, 110, 2131-2136.

34. Salant H, Markovics A, Spira DT, Hamburger J. 2007. The development of a molecular approach for coprodiagnosis of Toxoplasma gondii. Veterinary Parasitology, 146, 214-220.

35. Sayin F, Dincer S, Milli U. 1980. The life cycle and pathogenicity of Eimeria arloingi in Angora kids and an attempt at its transmission to lambs. Zoonoses and Public Health, 27, 382-397.

36. Sharma RL, Bhattacharya D, Laha R, Biswas JC, Rangarao GSC. 1997. Preliminary observations on intestinal Coccidiosis in Pashmina (Cashmere) goats in India. Journal of Applied Animal Research, 12, 107-112.

37. Silva LM, Vila-Viçosa MJ, Nunes T, Taubert A, Hermosilla C, Cortes HC. 2014. Eimeria infections in goats in Southern Portugal. Brazilian Journal of Veterinary Parasitology, 23, 280-286.

38. Tamura K, Stecher G, Peterson D, Filipski A, Kumar S. 2013. MEGA6: molecular evolutionary genetics analysis version 6.0. Molecular Biology and Evolution, 30, 2725-2729.

39. Tomczuk K, Grzybek M, Szczepaniak K, Studzińska M, Demkowska-Kutrzepa M, Roczeń-Karczmarz M, Klockiewicz M. 2015. Analysis of intrinsic and extrinsic factors influencing the dynamics of bovine Eimeria spp. from central-eastern Poland. Veterinary Parasitology, 214, 22-28.

40. Vercruysse J. 1982. The coccidia of sheep and goats in Senegal. Veterinary Parasitology, 10, 297-306.

41. Verma R, Sharma DK, Gururaj K, Paul S, Banerjee PS, Tiwari J. 2007. Molecular epidemiology and point mutations in ITS1 and 18S rDNA genes of Eimeria ninakohlyakimovae and E. christenseni isolated from Indian goats. Veterinary Parasitology: Regional Studies and Reports, 9, 51-62.

42. Wang CR, Xiao JY, Chen AH, Chen J, Wang Y, Gao JF, Zhu XQ. 2010. Prevalence of coccidial infection in sheep and goats in northeastern China. Veterinary Parasitology, 174, 213-217.

43. Williams RB. 2001. Quantification of the crowding effect during infections with seven Eimeria species of the domesticated fowl: its importance for experimental designs and production of oocyst stocks. International Journal of Parasitology, 31, 1056-1069.

44. Woji AY, Little DA, Ikwuegbu OA. 1994. Prevalence of coccidial infections in the West African Dwarf goat in the subhumid zone of Nigeria. Tropical Animal Health and Production, 26, 1-6.

45. Woods WG, Whithear KG, Richards DG, Anderson GR, Jorgensen WK, Gasser RB. 2000. Single-strand restriction fragment length polymorphism analysis of the second internal transcribed spacer (ribosomal DNA) for six species of Eimeria from chickens in Australia. International Journal of Parasitology, 30, 1019-1023.

46. Zhao X, Duszynski DW, Loker ES. 2001. Phylogenetic position of Eimeria antrozoi, a bat coccidium (Apicomplexa: Eimeriidae) and its relationship to morphologically similar Eimeria spp. from bats and rodents based on nuclear $18 \mathrm{~S}$ and plastid $23 \mathrm{~S}$ rDNA sequences. Journal of Parasitology, 87, 1120-1123. 
Cite this article as: Bawm S, Win TZ, Win SY, Htun LL, Nakao R \& Katakura K. 2020. First detection of Eimeria species in Myanmar domestic goats with both microscopic and molecular methods. Parasite 27, 38.

\section{(0) PARASTE}

An international open-access, peer-reviewed, online journal publishing high quality papers on all aspects of human and animal parasitology

Reviews, articles and short notes may be submitted. Fields include, but are not limited to: general, medical and veterinary parasitology; morphology, including ultrastructure; parasite systematics, including entomology, acarology, helminthology and protistology, and molecular analyses; molecular biology and biochemistry; immunology of parasitic diseases; host-parasite relationships; ecology and life history of parasites; epidemiology; therapeutics; new diagnostic tools.

All papers in Parasite are published in English. Manuscripts should have a broad interest and must not have been published or submitted elsewhere. No limit is imposed on the length of manuscripts.

Parasite (open-access) continues Parasite (print and online editions, 1994-2012) and Annales de Parasitologie Humaine et Comparée (1923-1993) and is the official journal of the Société Française de Parasitologie. 